\title{
Reviewer Acknowledgment
}

The International Journal of Play Therapy is very fortunate to have a dedicated Editorial Advisory Board that works tirelessly to review manuscripts for this publication. Because of the number of manuscripts that are submitted to the journal, we also rely on ad hoc reviewers to make sure that manuscripts are reviewed in a timely way. This past year, several ad hoc reviewers graciously agreed to assist in reviewing manuscript submissions. We thank the following individuals for their assistance in this integral step of the manuscript submission process.

Nick Cornett

Janet Anne Courtney

Rick Gaskill

Robert Jason Grant

Alexis Greeves
Wendy Helker

Phyllis Post

Heidi Gerard Kaduson

Sueann Kenney-Noziska

Terry Kottman

Yun-Jeong Kwon

Lacy Overley
April A. Schottelkorb

Angela Sheely-Moore

Jose Luis Tapia-Fuselier 